\title{
O BRASIL E A DISTANTE AMÉRICA DO SUL
}

\author{
Maria Ligia Coelho Prado \\ Depto. de História-FFLCH/USP
}

\section{Resumo}

Este artigo discute a elaboração de um discurso político original, no Brasil do século XIX, que fundou uma certa interpretação brasileira sobre o mundo hispano-americano, contribuindo para a constituição de um imaginário sobre a outra América, que a dissocia e a separa do Brasil. Tomo dois momentos precisos, a década de 1820 e os primeiros anos da república, lendo textos de políticos e intelectuais.

\section{Abstract}

This article deals with the elaboration of an original discourse, in Brazil, during the $19^{\text {th }}$ century, that emphasizes a Brazilian interpretation about the Hispanic American world, separating the other America from Brazil. I take two moments, the decade of 1820, and the first years of the republican regime, reading texts of politicians and intelectuals.

\section{Pallavras-Chave}

Brasil - América do Sul - política .

\section{Keywords}

Brazil - South America - politics. 
dmundo O’Gorman, em seu clássico A Invenção da América, afirma que, sem contradição lógica, a América é, e ao mesmo tempo, não é a Europa, "condição dramática de sua existência e chave de seu destino" (O’Gorman 1958: 94). Podemos afirmar igualmente que - como dois pólos que se atraem e se repelem - o Brasil é e, ao mesmo tempo, não é América Latina. Esta existência contraditória me leva a propor uma reflexão sobre o distanciamento político e cultural entre o Brasil e os demais países da América Latina de colonização espanhola. A explicação mais simples para esse fenômeno começa invariavelmente pela afirmação de que a cultura brasileira está profundamente marcada por uma tradição eurocêntrica, responsável, portanto, pelo fato do país estar de olhos postos na Europa e de costas para a América Latina. Ainda que esta indicação seja indiscutível, permanece demasiadamente genérica, fechando-se nela mesma.

Algumas constatações sobre o passado histórico das duas Américas - a portuguesa e a espanhola - são também inelutáveis. As metrópoles ibéricas desenharam limites não apenas geográficos, mas também culturais e políticos que dividiram suas colônias e criaram interesses econômicos e sociais específicos para cada região. E as independências não solucionaram esse impasse e não promoveram a tão proclamada necessidade de união entre todos os americanos do sul.

Neste texto, pretendo entender, pelo menos em parte, o fosso que nos separa, fazendo outra abordagem e aceitando, desde já, a complexidade da tarefa. Escolhi dois momentos da história brasileira para analisar este problema: o primeiro, o da construção do Estado Nacional e das conseqüentes definições de seu território. Tomo textos de jornais, de historiadores e políticos, relacionando-os com a situação peculiar do Brasil, naquele período, no concerto dos Estados latino-americanos. A República, instalada no fim do século XIX, que trouxe significativas mudanças políticas para o país, é o segundo momento. Para esse período, optei por trabalhar com escritos de historiadores e críticos literários, acompanhando a permanência da perspectiva brasileira com relação a seu distanciamento das demais nações latinoamericanos. Meu recorte privilegiou as relações entre Brasil, de um lado, e Argentina e Uruguai, de outro. Entretanto, as reflexões brasileiras sobre os dois países 
trabalharam, em geral, com identificações generalizantes que os aproximavam do conjunto das nações colonizadas pelos espanhóis ${ }^{1}$.

Todos esses autores elaboraram um discurso original - recheado de idéias, imagens e símbolos - que fundou uma interpretação brasileira sobre o mundo hispanoamericano. Penso que a repetição continuada dos mesmos argumentos contribuiu para a constituição de um imaginário - que acabou por forjar uma memória coletiva - sobre a outra América, dissociando-a, separando-a do Brasil (Nora 1984).

$$
* * *
$$

Para acompanhar o movimento de construção de uma maneira de pensar a história do Brasil, é necessário lembrar a criação do Instituto Histórico e Geográfico Brasileiro (I.H.G.B.), em 1838, cujas atividades deveriam se pautar - segundo o discurso de seu primeiro secretário, Januário da Cunha Barbosa - por duas diretrizes centrais: a coleta de documentos e o incentivo ao ensino da História do Brasil ${ }^{2}$.

Nesse momento, o I.H.G.B. promoveu o célebre concurso internacional, "Como se deve escrever a História do Brasil", vencido pelo alemão Karl Friedrich Philipp von Martius, que visitara o país anteriormente. Afirmava ele, em 1843 - portanto, quando o Rio Grande do Sul lutava por uma república separatista - em seu artigo, que no Brasil, havia muita gente com “idéias políticas imaturas". Referia-se às idéias republicanas, que ele repudiava. Entendia que se devia escrever a História do Brasil, pensando fundamentalmente nesses republicanos, pois era preciso convencê-los da inexeqüibilidade de seus projetos "utópicos", da inconveniência dessas discussões e da necessidade "de uma Monarquia em um país onde há um tão grande número de escravos" (Martius 1844: 410). Para ele, o Brasil apenas começava a entenderse como um todo unido e por isso mesmo, urgia que o historiador procurasse "provar

\footnotetext{
${ }^{1}$ Embora opiniões e propostas dos dois lados das fronteiras se entrecruzem, estudo poucos textos de autores argentinos ou uruguaios.

${ }^{2}$ Cf. Guimarães 1998: 8 e 10. A análise de Guimarães demonstra claramente as ligações umbelicais entre as finalidades do I.H.G.B. e os objetivos centralizadores da monarquia brasileira. Sobre o I.H.G.B., ver também (Schwarcz 1993).
} 
que o Brasil, país tão vasto e rico em fontes variadíssimas de ventura e prosperidade civil, alcançará o seu mais favorável desenvolvimento, se chegar, firmes os seus habitantes na sustentação da Monarquia, a estabelecer, por uma sábia organização entre todas as províncias, relações recíprocas". Para concluir, advertia que o historiador brasileiro "para prestar um verdadeiro serviço à sua pátria deverá escrever como autor monárquico-constitucional, como unitário no mais puro sentido da palavra" (Martius 1844: 411). Enfatize-se que este texto teve grande repercussão e fundou uma linhagem interpretativa da História do Brasil, copiada à exaustão em manuais escolares, em artigos de jornais, em discursos políticos etc.

A breve referência de von Martius à escravidão me leva a uma pequena digressão. Em suas “impressões” de viagem ao Rio de Janeiro, Domingo Faustino Sarmiento, figura exponencial do cenário político argentino, expressava sua estranheza diante do mundo brasileiro, tão diferente do que ele conhecia. Em primeiro lugar, ele estava nos "trópicos", sobre os quais tinha os mais negativos sentimentos, seguindo a leitura de Montesquieu ${ }^{3}$. Em segundo lugar, o Brasil era a terra da escravidão, que se apresentava no Rio de Janeiro "em toda sua deformidade" ". Sua visão negativa sobre o Brasil relacionava-se ao convívio entre brancos e escravos, já que os negros eram "incapazes de elevar-se às altas regiões da civilização" (Sarmiento 1993: 59). "A raça branca no Rio de Janeiro está castigada pelas doenças africanas, que participam do caráter odioso e deforme das degenerações dos trópicos, nos quais o que não chega a ser belo, é monstruoso e repugnante" (Sarmiento 1993: 58). Dessa maneira, a diferença era percebida por Sarmiento em outros termos. A Argentina não deveria ser confundida com essa terra de "deformidades" e "degeneração".

\footnotetext{
${ }^{3}$ Sarmiento escreveu, em 1845, seu Facundo, sem nunca ter visto os pampas e jamais ter pisado em Buenos Aires. Para compor o livro, utilizou-se de leituras de viajantes europeus que visitaram a região. Assim, ele vê o Brasil, já com um "quadro mental" fortemente construído a partir de leituras dos europeus.

${ }^{4} \mathrm{~A}$ historiografia brasileira já discutiu amplamente a questão da manutenção da escravidão e a relação com a vigência da integridade territorial brasileira. O próprio von Martius indicava a importância da monarquia num país com um número tão elevado de escravos.
} 
Voltando aos textos brasileiros, não encontrei na História Geral do Brasil de Francisco Adolfo Varnhagen, Visconde de Porto Seguro e sócio emérito do I.H.G.B., que foi publicada entre 1854 e 1857, referências tão claras à oposição entre o Brasil e a América Espanhola. Uma das raras indicações, que deixava entrever sua perspectiva sobre a outra América, pode ser identificada, quase ao fim do livro, quando diz: "Esquecer a nação pela província, [...] é um sintoma de dissolução política: é o princípio de um estado de coisas como o de Centro-América" (Varnhagen 1981: 177).

Como já foi indicado pelos analistas de sua produção, Varnhagen consagrava a monarquia como regime ideal, louvava a figura de D. Pedro I e invocava a Divina Providência como guardiã da unidade nacional ${ }^{5}$. O destino unitário do Brasil, nas páginas do Visconde de Porto Seguro, revelava-se, desde o período colonial, com a vitória portuguesa/brasileira sobre as assim denominadas invasões estrangeiras. $\mathrm{O}$ esmagamento das tentativas radicais republicanas de independência, como na Inconfidência Mineira, na Revolta dos Alfaiates ou na Revolução Pernambucana de 1817, também demonstrara ter sido “acertado". Nesses momentos, a República nos espreitara e poderia ter comprometido a unidade nacional. Afirmava Varnhagen sobre 1817: “Assim, ainda desta vez (e não foi a última) o braço da Providência, bem que à custa de lamentáveis vítimas e sacrifícios, amparou o Brasil, provendo em favor de sua integridade" (Varnhagen 1981: 177).

Varnhagen e von Martius eram "autoridades" cujos textos se legitimavam por sua própria condição; o primeiro, "grande sábio alemão" e o segundo, historiador consagrado que "provava" o que dizia pela pesquisa em documentos "verdadeiros". Esses ideólogos do Império, que escreveram a história oficial do Brasil, defendiam a monarquia que se opunha às "repúblicas caóticas" da parte espanhola. Dessa maneira, estava clara a diferença que se devia estabelecer entre "nós" e "eles", entre

\footnotetext{
${ }^{5}$ Em sua História da Independência do Brasil, conclui o livro com as seguintes palavras: “Terminamos, pois, saudando, com veneração e reverência, a memória do príncipe FUNDADOR DO IMPÉRIO” (Varnhagen 1940: 389).
} 
o Brasil e os demais países da América do Sul, onde campeavam a desordem, a desunião e a fragmentação, todas alimentadas pelas idéias republicanas. O Brasil, em oposição, era forte, unido e, portanto, poderoso ${ }^{6}$.

A historiografia produzida pelo I.H.G.B. trabalhava com uma idéia de identidade interna que deveria ver o Brasil como o resultado da fusão das "três raças", o branco, o índio e o negro. Externamente, como muito bem já afirmou Guimarães, a identidade brasileira, no período, foi construída montando-se a oposição entre regimes políticos antagônicos, a monarquia e a república. Os demais países da América Latina eram potenciais inimigos políticos do Brasil e se constituíam na representação da barbárie (Guimarães 1998: 7).

Considero fundamental enfatizar que essas interpretações ganharam enorme projeção e foram difundidas nas escolas, nos jornais da Corte e das províncias, nos púlpitos, nos banquetes, nos discursos da Câmara e do Senado. Dessa maneira, foram sendo captadas pela sociedade, contribuindo decisivamente para a constituição de uma certa maneira de se pensar a relação distante entre o Brasil e a América do Sul. Lembrando a análise de Girardet, estas são "verdadeiras narrativas míticas” que têm uma dupla finalidade, a explicativa e a mobilizadora (Girardet 1987: 162). Ou tomando a idéia de Nicolas Shumway, esses textos podem ser considerados "fixõesguias", isto é, escritos necessários para que os indivíduos de uma sociedade aceitem um sentido de nação, uma identidade coletiva, um objetivo nacional (Shumway 1991: $\mathrm{XI}^{7}$. Esses discursos ganharam um caráter unívoco, articulado em torno de um núcleo central, a idéia da monarquia unificadora da nação.

$* * *$

\footnotetext{
${ }^{6}$ Entre os pensadores liberais, na Europa, a monarquia constitucional era comumente vista como o regime mais apropriado para os grandes Estados, sendo a República adequada aos pequenos Estados, seguindo a célebre classificação de Montesquieu. Vale lembrar, por exemplo, que Hegel entendia que na monarquia constitucional, forma por excelência do Estado Moderno, a liberdade civil estava melhor protegida. A forma de governo monárquico era "a última" a que chegara a história universal, não havendo melhor alternativa para seu tempo. Sobre Hegel, ver a análise de (Bobbio 1980: 135 segs).

${ }^{7} \mathrm{O}$ autor dialoga com (Morgan 1988).
} 
Tal visão expressa nessa produção textual não estava descolada dos acontecimentos recentes da história brasileira e relacionava-se com as rebeliões regionais internas e as guerras externas no Prata, ganhando sentido e se transformando em explicações perfeitamente compreensíveis e adequadas ao momento histórico.

É possível acompanhar a emergência desses argumentos desde a independência do Brasil. Para tanto, faz-se necessário lembrar algumas questões desde a chegada de D. João e de sua Corte ao Brasil, em 1808. A presença do rei no cenário americano aguçou as disputas coloniais entre Portugal e Espanha na América Meridional e estimulou as práticas expansionistas da Coroa portuguesa ${ }^{8}$.

Desde o início, em 1810, das lutas pela independência das colônias espanholas, Portugal (posteriormente também o Brasil) e Argentina disputaram o domínio sobre a Banda Oriental ${ }^{9}$. Em 1821, esta foi incorporada ao Brasil, com o nome de Província

\footnotetext{
${ }^{8}$ Portugal não esquecia as antigas ambições de ganhar controle, por exemplo, sobre a Colônia do Sacramento na entrada do Rio da Prata, perdida para a Espanha em 1777, com a assinatura do tratado de Santo Ildefonso, depois de um século de conflitos. Até Oliveira Lima, sobre quem falaremos mais adiante, admitia que D. João VI levara à frente uma política expansionista: "O reinado brasileiro de Dom João VI foi o único período de imperialismo consciente que registra a nossa história”. (apud Malatian 1998: 147).

${ }^{9}$ Quando José Artigas iniciou, em 1811, as lutas pela independência do futuro Uruguai, o império português entendeu que era o momento apropriado para atingir seus antigos objetivos, mobilizando suas forças para intervir na região. A movimentação e as propostas de Artigas eram consideradas perigosas particularmente para os objetivos unitários da Corte portuguesa, levando à primeira (e frustrada) intervenção portuguesa, na Banda Oriental, em 1811. Mas, do outro lado do estuário, Buenos Aires comandava as lutas pela independência da Espanha. Conquistando rapidamente seguidas vitórias, projetava manter sua hegemonia sobre os mesmos territórios que haviam composto o antigo Vice Reinado do Rio da Prata. Desse modo, tanto a Banda Oriental, quanto o Paraguai "deveriam" fazer parte das nascentes Repúblicas Unidas do Rio da Prata. Assim, as ambições portuguesas e portenhas se enfrentavam em torno do território do futuro Uruguai. Em 1816, quando Artigas lutava contra os Unitários portenhos e desagradava, com suas propostas radicais de confisco de terras, a elite mercantil e proprietária da Banda Oriental, os portugueses novamente mandaram tropas por terra e por mar para a região, culminando suas ações com o cerco a Montevidéu. Receberam apoio de proprietários rurais e de comerciantes, descontentes com Artigas. Este acabou derrotado em 1820, deixando o território da Banda Oriental para sempre. Aproveitando-se da debilidade dos portenhos provocada pelas lutas políticas locais que os dividiam - os portugueses, temporariamente vitoriosos, incorporaram, em 1821, a Banda Oriental a seu império, com o nome de Província Cisplatina.
} 
Cisplatina. Com a independência brasileira, em 1822, o imperador D. Pedro I seguiu a política externa já estabelecida. A província Cisplatina "pertencia” ao novo país.

Mas ao lado das armas, outro combate tão importante quanto o primeiro, o das idéias, também acontecia. Buenos Aires entendia ser "natural” a incorporação da Banda Oriental às Províncias Unidas do Rio da Prata, pois significava a permanência das fronteiras estabelecidas durante o período colonial, indicando uma continuidade histórica. Em 1816, um jornal distinguia as diferenças entre as colonizações espanhola e portuguesa: "nada es peor que la dominación extranjera; y que dominación! Portuguesa!!! Que sin duda es peor que la española; pues son sin comparación más ignorantes, más supersticiosos y más intolerantes, y por eso se han unido para subyugarnos" $"$.

Do lado português/brasileiro, as justificativas apresentadas pelos contemporâneos, já desde 1808, centravam-se na idéia de que o território nacional tinha uma "fronteira natural" que ia do Amazonas ao Prata. Importante assinalar que tal "fronteira natural", ao sul, havia criado importantes interesses econômicos compartilhados por proprietários de fazendas na região Oriental e no Rio Grande do Sul, ligados a comerciantes do Rio de Janeiro ${ }^{11}$.

Portanto, não é de se admirar, manifestações públicas que defendiam a incorporação da Banda Oriental ao Brasil, denunciando a "usurpação" dos espanhóis do território que "sempre nos pertencera". Em 1823, uma carta de um leitor do Observador Constitucional transcrita no Diário do Governo, afirmava que a Banda Oriental estaria muito melhor sob a proteção e segurança do monarca português, pois “o resto da América Espanhola retalhado em estados diferentes, e muitos d'estes ainda divididos em partidos, mal pode cuidar cada um da sua segurança e arranjos internos, e muito menos concorrer por meio de socorros para a dos outros; que nestas

\footnotetext{
${ }^{10}$ La Crônica Argentina, 2a .ed. do n.30 de 8 de dezembro de 1816, citado por (Pimenta 1998: 136). ${ }^{11}$ Cf. (Pimenta 1998). Sobre o tema, ver também (Magnoli 1997). Manuel Luís Salgado Guimarães mostra que, no século XIX, a revista do Instituto Histórico e Geográfico Brasileiro tinha, em seus artigos, particular preocupação com a questão das fronteiras, especialmente, ao sul (Colônia da Sacramento), ao norte (com a Guiana Francesa) e ao centro-oeste (Mato Grosso). (Guimarães 1998: 23).
} 
circunstâncias é-lhe sem comparação mais vantajosa a sua incorporação ao Império do Brasil, poderoso, respeitado, e já na sua nascença solidamente baseado, como ele se acha, do que a outro qualquer Estado" ${ }^{12}$.

Nesse mesmo ano de 1823, um artigo do Diário do Governo enfatizava a superioridade do regime monárquico sobre o republicano: “À vista do que fica exposto podemos concluir com segurança que, se a América Espanhola abraçar o sistema Monárquico, modificado por uma Constituição sábia, sistema cuja utilidade lhe não é desconhecida, e chamar ao Trono a todo o custo uma Personagem de qualquer das Dinastias Reinantes, para desta sorte evitar as funestas consequiências da ambição dos naturais mais poderosos, a cujos caprichos tem sido até agora sacrificada, e segurar ao mesmo tempo a contemplação das Nações Estrangeiras, não só poderá contar com um mais pronto reconhecimento dos Soberanos da Europa, mas ainda com a eficaz cooperação do grandioso Império do Brasil (...)" ${ }^{13}$.

Assim, as justificativas da anexação já ensaiavam se sustentar no delineamento de uma oposição entre regimes políticos divergentes; de um lado, a fragilidade do regime republicano, "típico" da América Espanhola e, de outro, a solidez do regime monárquico brasileiro.

No entanto, as ambições brasileiras sobre o território da Banda Oriental começaram a ser soterradas em 1825. A luta dos uruguaios pela reconquista anulou os compromissos políticos com o Brasil e reintegrou a Banda Oriental ao território das Províncias Unidas do Rio da Prata. A guerra desencadeada entre Brasil e Argentina terminou sem vitoriosos. Com a arbitragem da Grã Bretanha, o Estado Oriental do Uruguai, como país soberano, nascia em 1828.

No Brasil, a guerra com a Argentina foi justificada com a utilização dos antigos argumentos que entendiam a Província Cisplatina como parte integrante e "natural" do império brasileiro. Do ponto de vista político, o embate entre império e república

\footnotetext{
${ }^{12}$ A carta é de 30 de janeiro de 1823, publicada no Diário do Governo, n.33 de 11 de fevereiro de 1823, citado por Pimenta 1998: 196-197.

${ }^{13}$ Diário do Governo, n.28, de 5 de fevereiro de 1823 (apud Pimenta 1998: 202).
} 
também despontava. Assim, apoiava o Diário Fluminense a guerra: "Fácil é de se conhecer o extraordinário temor, de que os pequenos Soberanos Argentinos estão possuídos vendo crescer tão desmarcadamente o Império do Equador. (...) Nenhum motivo fará com que Ele [S.M.I.] retire o seu escudo, e deixe nas margens do vulcão republicano uma Província, que a natureza fez parte constituinte do Império do Brasil; que nos tratados e convenções das Potências Européias foi julgada nossa (...)"14.

A guerra demonstrava que Buenos Aires continuava com suas aspirações de formação da "Grande" Argentina. Um dos argumentos em defesa da guerra contra o Brasil se baseava na associação entre a falta de respeito pelos direitos individuais e o regime monárquico. O jornal de Buenos Aires, Nacional, caracterizava a guerra como um conflito entre monarquia e república, anunciando para breve o desmoronamento do império brasileiro. Associava a idéia de liberdade ao regime republicano, indicando o "caráter" europeu e anti-americano do sistema político brasileiro. Em oposição, a república significava o rompimento com a Europa e marcava a dimensão de uma identidade americana presente em seu país.

Nas palavras de Garrido Pimenta: “[...] a figura de D. Pedro é tomada pelos republicanos como a própria personificação da guerra. As constantes referências depreciativas ao Imperador enfatizavam o fato de ele ser europeu e consequientemente anti-americano ('déspota luso-brasileiro', 'tirano europeu', 'o Nero do Continente Americano'), sendo comparado a Fernando VII como inimigo da América e ao execrado Agustín do México, 'tirano' e 'usurpador'. A guerra, então, se fazia contra o Imperador, e não contra o Brasil ou contra os Povos do Brasil que, em sendo americanos, teriam a mesma causa que os republicanos" (Pimenta 1998: 232).

Com a abdicação de D. Pedro I, em 1831, abriu-se com a menoridade do sucessor ao trono brasileiro, o período conhecido como o das Regências. Nesses anos, o Brasil foi sacudido por uma série de rebeliões de forte cunho regionalista, muitas delas propondo a separação do resto do país, constituindo-se em ameaçador perigo da dissolução "da ordem e da unidade" do Império. A mais longa dessas rebeliões foi

\footnotetext{
${ }^{14}$ Diário Fluminense, n.149, de 28 de dezembro de 1825, citado por Pimenta 1998: 209.
} 
a Farroupilha (1835-1845), no Rio Grande do Sul, que pôs em risco a manutenção das "fronteiras naturais" do sul do país. A tentativa de separação se alicerçava em propostas republicanas de governo, concretizadas na criação da República de Piratini. O fantasma da perda da Província Cisplatina rondava a corte imperial e o envolvimento de grupos uruguaios nas lutas indicava a permanência de interesses econômicos e políticos comuns, assim como de fronteiras bastante flexíveis.

A difícil e demorada derrota dos rebelados precisava ser legitimada com o reforço do discurso da unidade. Os círculos do poder monárquico insistirão na existência de uma íntima relação entre regime monárquico e unidade territorial, utilizando os mesmos argumentos anteriores, mas dando-lhes mais visibilidade, constância e acabamento. Assim, fechava-se uma interpretação que valorizava a monarquia, entendendoa como responsável pela manutenção da "grandeza" do território brasileiro, dádiva "natural" da Divina Providência e que demonizava as repúblicas hispânicas vítimas da "dolorosa fragmentação", fruto de sua "própria História".

Assim, na metade do século XIX, a região que hoje integra o Mercosul ainda mantinha relações políticas bastante conflitantes. Defendendo seus interesses na Argentina e Uruguai, o Brasil montou uma estratégia intervencionista para abrir espaço a governos mais favoráveis aos interesses brasileiros na região e foi muito bem sucedido em seus objetivos ${ }^{15}$.

\footnotetext{
${ }^{15}$ O Brasil trabalhou pela derrubada de Oribe, líder dos Blancos uruguaios, e do poderoso governador federalista de Buenos Aires, Juan Manuel de Rosas. Para tanto, aliou-se a seus inimigos internos, como o governador de Entre Rios, Justo José de Urquiza, e aos Colorados uruguaios e buscou (em vão) também aliados no Paraguai. Os resultados dessas intervenções foram muito positivos para o Brasil. Em 1851, Oribe era derrubado no Uruguai, refugiando-se temporariamente em Buenos Aires. Em 1852, na impressionante batalha de Caseros, em que se confrontaram 50.000 homens, Rosas caiu derrotado pelo conjunto de forças nacionais e estrangeiras. Finalmente foi assinada uma série de tratados com a república uruguaia, de interesse para o Brasil. Sobre esse tema ver Ferreira 1999: 147. A Guerra do Paraguai (1865-1870) demonstraria, mais à frente, que os interesses regionais em torno das bacias dos rios da Prata, Paraguai, Uruguai e Paraná continuavam a ser conflitantes. A disputa sobre a hegemonia da América do Sul permanecia forte. Vale lembrar outras questões que dividiam, nesse período, o Chile e a Argentina com relação ao extremo sul do continente, incluindo a passagem pelo Estreito de Magalhães. Sobre o tema ver (Cervo e Rapoport 1998).
} 
O autor do plano de intervenção - que culminou com a derrubada de Juan Manuel de Rosas, em 1852 - foi Paulino José Soares de Souza, futuro Visconde do Uruguai, figura fundamental na construção da política externa brasileira do período ${ }^{16}$. Em maio de 1852, expunha os motivos que teriam levado o Brasil a intervir na região do Prata: “Os esforços feitos pelos generais Rosas e Oribe para separar do Império a província do Rio Grande do Sul; a maneira pela qual cortejaram a rebelião de 1835, e contribuíram para que engrossassem as exageradas pretensões de fazer reviver o nulo tratado de 1777 , e de recobrar os povos de Missões que conquistamos, e dos quais há tão largo tempo estamos de posse; as continuadas tropelias, violências e extorsões cometidas sobre súditos e propriedades brasileiras no território Oriental e na fronteira, pondo em agitação a província do Rio Grande do Sul, e tornando iminente um rompimento de um dia para o outro, são circunstâncias que nos deviam fazer desejar e empenhar todos os esforços para uma solução definitiva dessas questões, que, arredando os perigos iminentes da posição em que se achava o Império, nos oferecessem garantias e nos permitissem viver tranqüilos" ${ }^{17}$. Afirmava ainda que Rosas pretendia acabar com a monarquia, "planta exótica" no solo americano e promover uma rebelião de escravos. A luta contra Rosas e Oribe também tinha como justificativa o embate contra "a opressão dos ditadores", idêntica à empregada, alguns anos depois, contra Solano López no Paraguai. Note-se, ainda, a importância dada no texto às ligações entre o Uruguai e a província do Rio Grande do Sul que "havia sido pacificada" fazia apenas sete anos.

O Visconde do Uruguai também resumia a política externa do Brasil no período do Império. O país deveria ter um lugar hegemônico na América do Sul, mantendo distância de seus vizinhos, não considerados como "iguais". A monarquia brasileira havia demonstrado, na ótica desses políticos e publicistas, sua "natural" superioridade. O Brasil continuava a olhar para a Europa, vale dizer Grã Bretanha e França, fonte irradiadora da "cultura, do progresso e da civilização". Tais valores não poderiam ser encontrados nos vizinhos que nos rodeavam.

\footnotetext{
${ }^{16}$ Ele foi ministro dos Negócios Estrangeiros entre outubro de 1849 a setembro de 1853.

${ }^{17}$ apud (Ferreira 1999: 146).
} 
As ligações entre os acontecimentos das duas primeiras décadas posteriores à independência e os textos dos historiadores citados anteriormente - Varnhagen e von Martius - parecem-me bastante fortes. Os argumentos que ganharam sua plena forma com esses autores já vinham sendo gestados desde a emancipação do Brasil.

Acompanhando os argumentos dos historiadores e publicistas do Império, foi possível notar a ênfase dada às diferenças dos regimes políticos que marcavam o distanciamento entre Brasil e os demais países da América Latina. Afirmo que esses discursos tiveram constância e vigor, construindo um imaginário sobre a "outra" América e alargando o fosso que "nos" separava "deles". Nessa perspectiva, a derrubada do regime monárquico e a instalação da República, em 15 de novembro de 1889, deveria, em tese, inaugurar uma nova era nessas relações, fazendo o regime republicano mudar seu sinal de negativo para positivo.

Entretanto, as distinções entre Brasil e América de colonização espanhola permaneceram pelo período republicano, com a utilização dos mesmos argumentos previamente apontados. Importante ressaltar que a historiografia brasileira mostrou como os republicanos não produziram um discurso que opusesse fortemente os dois períodos políticos no país. A República, devedora das idéias positivistas, foi entendida como uma etapa necessária ao maior progresso da nação. A monarquia precisava ser superada, mas isto não significava destruir o que ela havia legado à nação, a começar pela "manutenção da unidade e grandeza do território". A figura de D. Pedro II permanecia impoluta, aparecendo como um monarca bem intencionado e preocupado com os grandes problemas do Brasil.

Como afirma Maria de Lourdes Janotti, as críticas à República, nos anos imediatamente posteriores à sua instalação, foram realizadas por grupos de republicanos já desiludidos e inconformados com a tibieza e a lentidão das mudanças. A República parecia não haver concretizado as esperanças tão almejadas. A idéia do Império, como uma exceção positiva no concerto das nações da América Latina, permanecia inalterada, atravessando a ruptura republicana (Janotti 1986: 213). 
No entanto, com a República, novas identidades ganhavam consistência. Estabeleceram-se linhas de simpatia com relação aos Estados Unidos, nesse tempo de afirmação do novo regime, significando mais um aprofundamento nos sulcos da trilha que afastava o Brasil dos países hispano-americanos. Em contraposição, aconteciam na América hispânica, no fimm do XIX e começo do XX, manifestações de busca de identidades alicerçadas nas raízes culturais hispânicas e na valorização da herança da colonização, não ocorrendo, portanto, as mesmas "afinidades eletivas".

De fato, no Brasil republicano, aconteceu uma tímida aproximação oficial com a América hispânica. No campo da História, é preciso assinalar a iniciativa da realização de um concurso público para a elaboração do primeiro manual escolar de História da América. Sintomaticamente, apresentou-se um único concorrente, Rocha Pombo, que teve seu texto aprovado e publicado, depois de um parecer positivo de Manuel Bomfim, um dos raros entusiastas da América Latina ${ }^{18}$.

O encontro intelectual entre autores brasileiros e hispano-americanos, demonstrando os dois universos em dissonância pode ser acompanhado nos escritos de um dos maiores críticos literários do começo do século XX, José Veríssimo. Ele escreveu, por exemplo, uma resenha do livro de José Enrique Rodó, Ariel, com o título de "Regeneração da América Latina" ". Começava o artigo criticando o autor pela escolha do próprio título do livro, dizendo que "em vez de seu título enigmático de fantasia artística, poderia levar o que dei a este artigo" (Veríssimo 1902: 23).

Publicado em 1900, Ariel valorizava as tradições hispânicas como fonte primordial da cultura latino-americana, e fora inspirado, pelo menos em parte, pela intervenção norte-americana na guerra hispano-cubana de 1898. Apropriando-se das

\footnotetext{
${ }^{18}$ É Manuel Bomfim que em seu A América Latina. Males de Origem, publicado em 1903, apresenta uma polêmica visão da América Latina, que vai se opor à corrente hegemônica. $\mathrm{O}$ autor vê a América de colonização espanhola com simpatia, não estabelecendo diferenças entre ela e o Brasil. Vale lembrar que Silvio Romero, considerado o "grande" crítico literário daquele momento, fazendo a crítica do livro, chamou-o de medíocre, "curto de inteligência" e outras acusações. (Romero 1910). ${ }^{19}$ Publicado em Homens e coisas estrangeiras, $1^{\text {a }}$. série, Rio de Janeiro, 1902 (apud Barbosa 1986: 17 e segs).
} 
personagens de Shakespeare em A Tempestade, Rodó construiu metáforas sobre as Américas. Ariel, gênio do ar, representava a parte nobre do espírito, o império da razão, a espiritualidade da cultura. Constituía-se, para ele, em símbolo da América Latina que se contrapunha a Calibán, o monstro que idolatrava a matéria, representação concreta dos Estados Unidos. A repercussão deste texto em toda a América de colonização espanhola foi enorme, criando-se até mesmo o substantivo "arielismo".

Não se imagine que Veríssimo desconhecesse a simbologia dos personagens de Shakespeare, pois a familiaridade com A Tempestade ficava indicada no decorrer do texto ${ }^{20}$. Suas diferenças passavam pela não aceitação da defesa das identidades propostas. Eis a visão de Veríssimo sobre a colonização espanhola: "Por ocasião da guerra hispano-cubana e da intervenção norte-americana nessa pugna, quem escreve estas linhas, com sua ojeriza pela civilização espanhola, feita de conquistas sanguinolentas, de inquisição, de fanatismo, e com seu sincero amor de ver livre o pequeno povo que há vinte e cinco anos estava lutando pela sua independência uma luta atroz e desigual, cometeu o grave erro de supor que, recordando o que elas mesmas sofreram do duríssimo domínio espanhol, e o que lhes custou libertarem-se dele, as nações hispano-americanas veriam, ao menos com indiferença, senão com satisfação, os Estados Unidos tomarem a parte daquela heróica população, como elas hispanoamericanas" (Veríssimo 1902: 24).

Mas para sua surpresa, tal não aconteceu. Pelo contrário, em outros países da América Latina a intervenção dos Estados Unidos despertou manifestações de hostilidade contra ela. Para o brasileiro, que demonstrava dificuldades para entender essas ligações, o livro de Rodó era "um sintoma do despertar do sentimento latino, ou antes, do sentimento espanhol na porção ibérica da América" (Veríssimo 1902: 24). Assim, o Brasil não podia ser enquadrado nessa moldura, indicando, mais uma vez, as distâncias que nos separavam.

\footnotetext{
${ }^{20}$ Não nos esqueçamos de que Ernest Renan, autor muito lido na América Latina, havia escrito Caliban, suíte de 'La Tempête'. Drame philosophique, Paris, 1878, no qual Caliban representava o povo e conspirava contra Próspero.
} 
Também é interessante seguir os argumentos de Veríssimo na resenha de outro livro, o do argentino Rodriguez del Busto, Peligros Americanos, em que este autor advertia para o perigo representado pela expansão dos Estados Unidos e apelava para a unidade latino-americana. O crítico brasileiro afirmava: "Tenho a fraternidade latino-americana, sinto-a intimamente; nunca, desde rapaz, participei do preconceito da minha gente, herdado do português e desenvolvido pelas nossas lutas no Rio da Prata, contra os povos espanhóis da América. Amo-os a todos e me revoltam as manifestações hostis a qualquer deles; mas não consigo ajeitar-me à idéia que eles possam sair tão cedo da miséria econômica, social e moral em que, salvo uma ou outra raríssima exceção, vivem" (Veríssimo 1902: 20). O primeiro ponto a ser ressaltado referese à sua constatação da pouca simpatia dos brasileiros em relação aos hispano-americanos. Em segundo lugar, vale assinalar algumas conclusões de Veríssimo sobre o futuro do continente. Para ele, pela seleção natural, à América Espanhola "não lhes caberá futuro próprio"; outros povos assumiriam essa tarefa no lugar deles. Em contrapartida, o futuro sorria para o Brasil, senhor de seu próprio destino.

O mesmo exercício de análise da exposição de semelhantes argumentos poderia ser realizado em diversos textos de outros autores conhecidos ${ }^{21}$. Entretanto, quero determe, por fim, na análise do consagrado historiador e diplomata, Oliveira Lima, que deixou obra extensa, parte dela dedicada a pensar o Brasil nas Américas. Considerada figura destacada como articuladora da política externa brasileira, foi comparado a Joaquim Nabuco, com quem formava "o par homérico de nossa diplomacia" (Orlando1906: 4).

Em América Latina e América Inglesa, escrito em 1912, o autor reproduzia uma série de conferências realizadas nos Estados Unidos, nas quais analisava "a evolução brasileira comparada com a da América hispânica e inglesa". De maneira discreta, porém clara, a defesa da monarquia estava presente. Ressaltando a importância do Império na manutenção da unidade nacional, afirmava que com a perpetuação no trono da dinastia portuguesa, "não só se arredava no Brasil a coroa do conflito das ambições, como se

\footnotetext{
${ }^{21}$ Refiro-me a autores como Eduardo Prado, Silvio Romero, Artur Orlando, Joaquim Nabuco. Ver sobre essa questão (Baggio 1998 e Capelato 2000).
} 
dotava a tradição nacional de um vigor e de um realce únicos, comparados com o que ocorria nos demais países do novo mundo espanhol ... A monarquia brasileira pode dizer-se por tantos motivos haver sido no século XIX o regime político verdadeiramente adequado ao "status' social da América Latina" (Lima s/d.: 167) ${ }^{22}$.

Para ele, a monarquia representou, "em um período anárquico para quase todo o resto do continente", a paz doméstica associada à liberdade. (Lima s/d.: 168) Dizia: "Em todo o caso constituiu o Brasil imperial um modelo de liberdade e de paz para a América Latina e forneceu pelo menos uma imagem não ilusória de civilização, ainda que refletida no trono, ao tempo que as sociedades hispano-americanas se debatiam na desordem e na selvageria" (Lima s/d.: 126). Isto porque lá existia um general caudilho, que ficava muito perto do "povo inculto". O caudilho dominava uma "multidão fascinada e inconsciente na qual prevalecia, em matéria social, um instinto comunista, e em matéria política, um pendor demagógico" (Lima s/d.: 127). Para tal pecado original, no entanto, havia resgate, pela moralização do trabalho e da educação. Além do Brasil, cujo passado sob a monarquia, fora "invejável", a Argentina também saíra do "atoleiro", constituindose em exemplo para os demais países da América Latina (Lima s/d.: 149).

Não surpreende constatar que a maior parte dos textos hispano-americanos citados por Oliveira Lima - e pelos brasileiros em geral - foi publicada na França, em geral, em francês. Como tantas vezes já se afirmou, Paris era o centro difusor de conhecimento sobre as letras latino-americanas. Oliveira Lima apoiava-se, no livro acima citado, em dois clássicos autores hispano-americanos, seus contemporâneos: o peruano Francisco García Calderón e o venezuelano, Rufino Blanco Fombona ${ }^{23}$. Para legitimar suas afirmações sobre a situação das sociedades hispano-americanas,

\footnotetext{
${ }^{22}$ Para uma análise recente e importante sobre Oliveira Lima, ver o trabalho já citado de (Malatian 1998).

${ }^{23}$ Esses dois autores citados por Oliveira Lima foram referências importantes na América do Sul. O livro mais importante de Francisco García Calderón, Las democracias latinas de América foi publicado, em 1912, em francês e traduzido ao espanhol 64 anos depois. Seu Perou Contemporain é de 1907. Blanco Fombona escreveu inúmeros enasios, entre eles, La evolución política y social de Hispanoamérica e La americanización del mundo. Sobre eles, ver os volumes 44 e 36 publicados pela Biblioteca Ayacucho de Caracas.
} 
recorria a Perou Contemporain de Garcia Calderón, afirmando que seus argumentos, que incluíam as idéias de anarquia, de constituições políticas enxertadas, de instintos seculares do povo, explicavam a situação "desastrosa" do Peru, e podiam ser estendidos a todo o império espanhol (Lima s/d.: 164). Para criticar o federalismo republicano da América Espanhola, Oliveira Lima, depois de arrolar exemplos de vários ditadores hispano-americanos, citava Blanco Fombona que, segundo ele, resumia com felicidade a situação da América Espanhola, onde: "impera o cacique, e sobre este amiúde o rábula, o charlatão, que o chefe intonso admira e o povo analfabeto aplaude" (Lima s/d.:170).

Nota-se, assim, que a repetição em seu texto de um termo como "anarquia", para definir a América Espanhola se legitimava na medida em que os próprios hispano-americanos faziam uso dele. Ainda uma vez, eram duas Américas, uma da ordem, da paz e da unidade e a outra, do individualismo nefasto (o exemplo de Rosas na Argentina era comumente lembrado), do caos, da anarquia, da fragmentação. Mesmo em plena República, o imaginário sobre a identidade nacional combinava à idéia de unidade, a de ordem garantida pelo regime monárquico.

Interessante é acompanhar o livro de García Merou, muito citado por Oliveira Lima, El Brasil intelectual. Impresiones y notas literarias. Publicado em 1900, o autor indagava, logo no início do texto, das razões do distanciamento entre Argentina e Brasil, enfatizando a mútua ignorância com relação às respectivas produções intelectuais. Contrariando a regra, o conhecimento de García Merou sobre os autores brasileiros do período é notável. Em termos de política, entendia que tínhamos todas as condições para nos aproximar, já que as desavenças do passado não mais encontravam razão de ser. Afirmava que, no começo do século XX, enfrentávamos problemas semelhantes e nos norteávamos por princípios políticos comuns. Entretanto, ainda que republicano convicto, não escapava da interpretação dominante sobre o período imperial brasileiro. Explicando a ausência de caudilhos no Brasil, afirmava ele: "É um bem apreciável que devem os brasileiros à larga estabilidade do regime monárquico, e que, apesar da mudança das instituições, foi estabelecido já um costume e uma necessidade pública difícil de quebrar" (García Merou 1900: 439). 
Como García Merou, Oliveira Lima acreditava na possibilidade de um encontro entre as Américas portuguesa e espanhola. No passado, dizia, houvera hostilidades, mas no momento em que escrevia os interesses eram por demais análogos e comuns a ambas, havendo uma recíproca conveniência de aproximação, que para ele, se desenhava a cada dia mais pronunciada e mais firme (Lima s/d.: 167).

$\mathrm{Na}$ defesa de suas posições, no livro Na Argentina, editado em 1920, Oliveira Lima citava o estadista argentino, professor da Faculdade de Direito de Buenos Aires, Estanilaos S. Zeballos, concordando com sua proposta de união das três maiores potências da América do Sul - o Brasil, a Argentina e o Chile. Afirma que o argentino "por ocasião de seu último ministério tentou com afinco negociar um tratado de comércio com o Brasil, vantajoso para ambas as partes, e esboçou mesmo o plano de uma aliança defensiva entre as três nações, que não foi por diante porque ciúmes nacionais e estrangeiros lhes foram de encontro. Não havia nesse projeto, mais tarde retomado com o nome de A B C e malogrado por outros motivos, visos de agressão, quer aos Estados Unidos, quer à Europa: apenas entendia o estadista argentino que um bloco latino-americano ofereceria vantagens decididas no sentido de fazer respeitar, não só a integridade territorial como a soberania das nações componentes do acordo e conseguintemente do continente colonizado pelo esforço ibérico" (Lima 1920: $166-167)^{24}$.

Na carreira diplomática, Oliveira Lima e Joaquim Nabuco representaram duas tendências opostas. Enquanto Oliveira Lima entendia que a política externa do Brasil devia tomar a direção de aproximação com os países da América espanhola, particularmente da Argentina e do Chile, Nabuco era um "americanófilo" de primeira hora. O todo poderoso Barão do Rio Branco, na sua qualidade de ministro, aparentava um certo distanciamento entre as posições defendidas. Entretanto, suas atitudes demonstraram que apoiou Joaquim Nabuco. Reveladores dessa decisão foram os postos

\footnotetext{
${ }^{24}$ A proposta de Zaballos parece ser de 1910.
} 
designados a eles por Rio Branco: enquanto Oliveira Lima era enviado a Caracas e Bruxelas, a Nabuco ficavam reservados Londres e Washington.

Nesse embate, a publicação, em 1907, de Pan-americanismo (Monroe, Bolívar, Roosevelt), havia se constituído em marco divisor na carreira de Oliveira Lima. Nesse livro, suas posições de ataque à política externa dos Estados Unidos se apresentaram de forma mais contundente, pretendendo mostrar os perigos futuros que adviriam dela com relação ao Brasil e à América Latina. Para o autor, era ingenuidade acreditar que a Doutrina Monroe fora pensada em benefício dos países da América Latina, para supostamente defendê-los da Europa. A doutrina beneficiava os interesses dos Estados Unidos mais claramente identificados, no começo do século XX, com as atitudes intervencionistas do governo de Theodore Roosevelt. Opunha-se ao "rooseveltismo" de Nabuco, para quem os países latino-americanos deviam sentir "simpatia e gratidão" diante dos Estados Unidos (Lima 1980: 67) ${ }^{25}$. Tal posição determinou seu rompimento definitivo com Nabuco e Rio Branco, acarretando-lhe perdas profissionais e levando-o, em 1913, a solicitar sua aposentadoria da carreira diplomática. A derrota de Oliveira Lima no plano diplomático significou a perda de uma possibilidade de aproximação oficial com a os países do ABC e a vitória da posição de alinhamento do Brasil nas fileiras do pan-americanismo capitaneado pelos interesses dos Estados Unidos.

Desse modo, com a República, não se alteraram substancialmente as relações diplomáticas com os demais países da América Latina. Esta posição se coadunava com a manutenção de um sentimento anti-hispânico bastante acentuado, conforme foi indicado nos textos analisados. A República não destruiu as distâncias entre o Brasil e a América Hispânica, pois as diferenças, muito mais que as semelhanças, continuavam a ser destacadas. As visões da distância que nos separava contribuíram para a construção de um imaginário que forjou uma memória transformada em senso comum e que remetia ao passado histórico apresentado como legitimador do presente.

$* * *$

\footnotetext{
${ }^{25}$ Sobre as relações entre o Brasil e os Estados Unidos, ver (Prado 2000).
} 
O historiador, como muito bem já assinalou Marc Bloch, deve estar atento ao presente, a tudo que é vivo e está a seu redor (Bloch 1974). A criação do Mercosul, sem dúvida, colocou problemas e questões ao historiador da América Latina. Sua existência fez surgir indagações particulares sobre as específicas relações - não simplesmente relações econômicas - entre os países componentes do bloco. Este texto nasceu exatamente de algumas inquietações criadas por esta nova situação. Olhando para o futuro, cabe indagar se o Mercosul levará a mudanças na esfera das relações culturais? Será possível transformar velhas imagens e idéias? Esses novos ventos levarão à elaboração, no Brasil, de outras concepções sobre a América Latina, em particular sobre a América do Sul, trazendo-a para mais perto dos brasileiros?

Termino com uma certeza e uma dúvida. A primeira se refere à constatação de como é difícil pensar a América Latina a partir do Brasil, onde não existe uma tradição de estudos latino-americanos. Os ricos e férteis resultados que se obteriam, caso perseguíssemos as trilhas abertas pela História Comparada da América Latina, parecem-me evidentes. A indagação que continuo a fazer refere-se às concretas possibilidades do despertar de uma nova visão brasileira com relação a essa outra América, tão próxima e, ao mesmo tempo, tão distante.

\section{Referências Bibliográficas}

BAGGIO, Kátia Gerab. A "Outra" América: A América Latina na visão dos intelectuais brasileiros das primeiras décadas republicanas. São Paulo, Departamento de História da USP, 1998. (tese de doutoramento).

BLOCH, Marc. Introdução à História. Lisboa, Publicações Europa-América, 1974.

BOBBIO, Norberto. A teoria de governo. Brasília, Editora da universidade de Brasília, 1980.

BOMFIM, Manuel. A América Latina. Males de Origem. Rio de Janeiro, Topbooks, 1993.

CAPELATO, Maria Helena Rolim “O 'gigante brasileiro' na América Latina: ser ou não ser latino-americano". in MOTA, Carlos Guilherme (org.). Viagem incompleta: a experiência brasileira. A grande transação. São Paulo, Editora SENAC, 2000.

CERVO, Amado Luiz e RAPOPORT, Mario (orgs.). História do Cone Sul. Rio de Janeiro: Revan; Brasília: Editora UnB, 1998. 
FERREIRA, Gabriela Nunes. Centralização e descentralização no Império. O debate entre Tavares Bastos e o Visconde do Uruguai. São Paulo, Departamento de Ciência Política da USP/Editora 34, 1999.

GARCÍA MEROU, Martín. El Brasil intelectual, Impresiones y notas literárias. Buenos Aires, Felix la Jouane, 1900.

GIRARDET, Raoul. Mitos e mitologias políticas. São Paulo, Companhia das Letras, 1987.

GUIMARÃES, Manuel Luís Salgado. "Nação e civilização nos trópicos: o Instituto Histórico e Geográfico Brasileiro e o projeto de uma História Nacional”. Estudos Históricos, no 1, 1998.

JANOTTI, Maria de Lourdes Mônaco. Os subversivos da República. São Paulo, Brasiliense, 1986.

LIMA, Oliveira. América Latina e América Ingleza. Rio de Janeiro, Livraria Garnier, s.d. Na Argentina. São Paulo e Rio de Janeiro, Weisflog Irmãos, 1920.

Pan-americanismo. Brasília: Senado Federal; Rio de Janeiro: Fundação Casa de Rui Barbosa, 1980.

MAGNOLI, Demétrio. O corpo da pátria: imaginação geográfica e política externa no Brasil (1808-1912). São Paulo, Editora da UNESP/Moderna, 1997.

MALATIAN, Teresa Maria. Oliveira Lima: Historiador diplomata. Departamento de História, UNESP - Campus de Franca, 1998.(tese de livre docência).

MARTIUS, Karl Friedrich Philipp von. "Como se deve escrever a História do Brasil”. Revista do IHGB, tomo VI, 1844.

MORGAN, Edmund S. Inventing the people. Nova York, Norton, 1988.

NORA, Pierre (org). Le lieux de mémoire - La République. Paris, Gallimard, 1984.

O'GORMAN, Edmundo. La invención de América. México. Fondo de Cultura Económica, 1958.

ORLANDO, Artur. Introdução a Oliveira Lima. Pan-americanismo. Rio de Janeiro: Tipografia do Jornal do Comércio, 1906.

PIMENTA, João Paulo Garrido. Estado e nação na crise dos impérios ibéricos. Departamento de História, USP, 1998. (dissertação de mestrado).

PRADO, Maria Ligia Coelho. "Davi e Golias: as relações entre Brasil e Estados Unidos no século XX". in MOTA, Carlos Guilherme (org.). Viagem incompleta: a experiência brasileira. A grande transação. São Paulo, Editora SENAC, 2000.

ROMERO, Silvio. “A propósito da América Latina”. Provocações e debates. Porto, Livraria Chardron de Lello e Irmão, 1910. 
SARMIENTO, Domingo Faustino. Viajes. Espanha, Archivos, CSIC, 1993.

Facundo, civilização e barbárie. Petrópolis, Vozes, 1997.

SCHWARCZ, Lilia M.O espetáculo das raças. São Paulo, Companhia das Letras, 1993.

SHUMWAY, Nicolas. The invention of Argentina. Berkeley, University of California Press, 1991.

VARNHAGEN, Francisco Adolfo de. História da Independência do Brasil. Rio de Janeiro, Imprensa Nacional, 1940.

. História Geral do Brasil. 10ª ed., Belo Horizonte: Itatiaia; São Paulo: Editora da Universidade de São Paulo, 1981.

VERÍSSIMO, José. "Regeneração da América Latina." in BARBOSA, João Alexandre (org.). Cultura, literatura e política na América Latina. São Paulo: Brasiliense, 1986. 